Brazilian Journal

of Chemical

ISSN 0104-6632

Engineering

\title{
FODDER RADISH CAKE (Raphanus sativus L.) AS AN ALTERNATIVE BIOMASS FOR THE PRODUCTION OF CELLULASES AND XYLANASES IN SOLID- STATE CULTIVATION
}

\author{
L. Zukovski ${ }^{1}$, R. C. Fontana ${ }^{1}$, G. Pauletti ${ }^{1}$, M. Camassola ${ }^{1}$ and A. J. P. Dillon ${ }^{1}{ }^{*}$ \\ Enzymes and Biomass Laboratory, Institute of Biotechnology, University of Caxias do Sul, \\ Francisco Getúlio Vargas Street 1130, 95070-560, Caxias do Sul, RS, Brazil. \\ *E-mail: ajpdillo@ucs.br; Phone/Fax:+55 5432182149
}

(Submitted: December 23, 2015; Revised: March 26, 2016; Accepted: May 10, 2016)

\begin{abstract}
Fodder radish (FR) is an oilseed crop with a high potential for biodiesel production due to its high productivity and the quality of its seed oil. FR oil extraction results in a residue that is rich in protein and fiber. In this study, FR cake (FRC) was evaluated as carbon and nitrogen source for the production of cellulases and xylanases using Penicillium echinulatum S1M29 during solid-state cultivation. It was determined that it is possible to partially replace wheat bran (WB) by FRC, resulting in $24.22 \pm 0.25 \mathrm{U} / \mathrm{g}$ Filter Paper Activity (144 hours), $210.5 \pm 5.8 \mathrm{U} / \mathrm{g}$ endoglucanase activity (144 hours), $22.62 \pm 0.01 \mathrm{U} / \mathrm{g} \beta$-glucosidase activity (96 hours) and $784.7 \pm 70.19 \mathrm{U} / \mathrm{g}$ xylanase activity (120 hours). These values are equal or higher than the enzymatic activity obtained using WB. These results may contribute to the reduction of the cost of enzymes used in the production of cellulosic ethanol or other biotechnological applications.
\end{abstract}

Keywords: Cellulases; Xylanases; solid-state cultivation; Fodder radish cake; Penicillium echinulatum.

\section{INTRODUCTION}

In recent decades, the enzymatic hydrolysis of cellulose from lignocellulosic residues has been widely studied because cellulosic biomass is a possible resource for alternative fuel production. Additionally, this process has a great potential for reducing carbon dioxide emissions, thereby contributing to reducing global warming. However, to convert lignocellulosic biomass into biofuel, specifically ethanol, it is necessary to perform hydrolysis on the biomass, which requires enzymes, particularly cellulases and xylanases (Basso et al., 2014; Mabee et al., 2011; Reis et al., 2014).

Cellulases are enzymes that hydrolyze 1,4-linked $\beta$-glycosidic cellulose, yielding glucose, cellobiose and cello-oligosaccharides as primary products. This enzyme complex comprises endoglucanases, cellobiohydrolases and $\beta$-glucosidases. $\beta$-glucosidases are not considered legitimate cellulases, but they have an important function during cellulose hydrolysis (Martins et al., 2008; Padilha et al., 2015). These enzymes act synergistically to convert cellulose into glucose (Mabee et al., 2011). Xylanases hydrolyze xylan polysaccharides, which are the major constituents of hemicellulose. Therefore, xylanases increase the efficiency of enzymatic hydrolysis, whereas hemicellulose inhibits cellulose degradation (Herold et al., 2013).

Both cellulases and xylanases can be produced in solidstate cultivation (SSC) or submerged cultivation (SC). Commercially, most cellulases and xylanases are produced

\footnotetext{
* To whom correspondence should be addressed
} 
by SC because the production factors are easier to control. However, the SC method can be complex because it involves mixing, aeration, and control and monitoring of temperature, $\mathrm{pH}$, dissolved oxygen and other factors (dos Reis et al., 2014; Reis et al., 2015), and the SC method requires specific equipment. Using SSC for enzyme production has attracted interest because it is a lower cost technology and has a relatively high enzyme production capacity (Camassola and Dillon, 2007; Camassola and Dillon, 2016; Macedo et al., 2013; Pirota et al., 2013; Yoon et al., 2014).

Among the microorganisms that can potentially produce cellulases that generate second-generation ethanol, Penicillium echinulatum mutants are notable because they have high enzymatic titers (Dillon et al., 2011) and produce appropriate proportions of FPA and $\beta$-glucosidase (Martins et al., 2008).

A major advantage of solid-state cultivation is the use of agricultural and agro-industrial residues (Camassola and Dillon, 2010). Agro-industrial residues include residues from the production of biodiesel, like fodder radish. Fodder radish has a rapid growth and high capacity to recycle nutrients, particularly nitrogen and phosphorus, developing reasonably in poor soils with acidity problems. It is important for crop rotation and produces great amounts of dry weight and is excellent for the practice of direct planting. Fodder radish enters the crop rotation system, minimizing soil compaction, producing green mass and reducing weed infestation during the fallow season of agricultural areas (Sluszz and Machado, 2006). Fodder radish produces 20 to $35 \mathrm{t} /$ ha green mass, 3.5 to $8 \mathrm{t} /$ ha of dry matter and 0.5 to $1.5 \mathrm{t} /$ ha grains. The oil productivity is around 150 to $550 \mathrm{~kg}$ / ha (Ávila and Sodre, 2012). Seeds of fodder radish (Raphanus sativus L.) derive $40-54 \%$ of their mass from oil (Domingos et al., 2008) and the postextraction residue of oil for biodiesel production contains approximately $39 \%(\mathrm{w} / \mathrm{w})$ protein and $5 \%(\mathrm{w} / \mathrm{w})$ minerals (Ávila and Sodré, 2012).

Additionally, fodder radish cake (FRC) is a promising residue that can be used in combination with lignocellulose for enzyme production. This study evaluated the potential of using FRC, alone and in combination with wheat bran (WB), as a substrate for the production of cellulase and xylanase during solid-state cultivation with P. echinulatum.

\section{MATERIALS AND METHODS}

\section{Microorganism}

The strain S1M29 of P. echinulatum was obtained from the strain 9A02S1 after several steps of hydrogen peroxide mutagenesis and selection in medium containing 2-deoxyglucose (Dillon et al., 2006). This strain was stored in the cultivation collection of the Enzymes and Biomass Laboratory, Institute of Biotechnology, Caxias do Sul, Rio Grande do Sul, Brazil. This strain was grown on C-agar slants (Dillon et al., 2011) for up to 7 days at $28^{\circ} \mathrm{C}$ until conidia formed and then was stored at $4^{\circ} \mathrm{C}$ until further use.

\section{Enzyme production}

WB and FRC were used as the support and primary carbon and nitrogen sources. The cultivation media consisted of a mixture of various ratios of WB and FRC, as specified in Table 1. The controls were WB and FRC alone.

The SSC was performed as described in Camassola and Dillon (2007, 2010) (Camassola and Dillon, 2010; Camassola and Dillon, 2007). The cultivation flasks were incubated at $28{ }^{\circ} \mathrm{C}$ and $90 \%$ humidity for 6 days. Four replicate experiments containing $2 \mathrm{~g}$ of dry mass biomass were performed for the same strains and each incubation time. The extraction of enzymes was done according to Camassola and Dillon (2007), the contents of each flask were separately added to a $125 \mathrm{~mL}$-Erlenmeyer flask containing $10 \mathrm{~mL}$ distilled water, and the $\mathrm{pH}$ was measured. Next, $17 \mathrm{~mL}$ of $0.05 \mathrm{M}$ citrate buffer (pH 4.8) was added, mixed, incubated under agitation for $30 \mathrm{~min}$ at $4{ }^{\circ} \mathrm{C}$ and then centrifuged at $3220 \times \mathrm{g}$ for $20 \mathrm{~min}$. Enzyme assays were performed on the broth samples as described below.

\section{Enzyme assay}

The enzymatic activity was analyzed on filter paper (Filter Paper Activity - FPA) according to Camassola and Dillon (2012). The $\beta$-glucosidase activity was determined using p-nitrophenyl- $\beta$-D-glucopyranoside as the substrate (Daroit et al., 2008). The endoglucanase activity was determined according to the method outlined by Ghose (1987) using $2 \%(\mathrm{w} / \mathrm{v})$ carboxymethyl cellulose solution

Table 1. Formulations used in the solid-state cultivation to produce xylanases and cellulases from Penicillium echinulatum S1M29.

\begin{tabular}{|c|c|c|}
\hline & WB (\%) & FRC (\%) \\
\hline Medium 1 (control) & 100 & 0 \\
\hline Medium 2 & 0 & 100 \\
\hline Medium 3 & 50 & 50 \\
\hline Medium 4 & 75 & 25 \\
\hline Medium 5 & 25 & 75 \\
\hline
\end{tabular}

WB - wheat bran; FRC - fodder radish cake. 
in citrate buffer. The xylanase activity was determined using the same method as the endoglucanase activity assay, except that $1 \%(\mathrm{w} / \mathrm{v})$ xylan from oat spelt solution was used as the substrate in place of carboxymethylcellulose. The reducing sugar was estimated as either the xylose or glucose equivalent using the dinitrosalicylic acid (DNS) method (Miller, 1959).

One unit (U) of enzyme activity was defined as the amount of enzyme required to liberate $1 \mu \mathrm{mol}$ of reducing sugar from the appropriate substrates per minute under assay conditions. The enzymatic activities are expressed as units per gram of dry medium $(\mathrm{U} / \mathrm{g})$.

\section{Mycelial Mass Determination}

Growth determinations were performed by determining the amount of N-acetyl-D-glucosamine present in the mycelium and converted fungal biomass according to the method described by Novello et al. (2014).

\section{Statistical tests}

The results were statistically analyzed using analysis of variance (ANOVA) and Tukey post-test using the Prism GraphPad program (GraphPad Software, Inc., USA). A p-value $<0.05$ was considered statistically significant.

\section{RESULTS AND DISCUSSION}

\section{Production of endoglucanases, $\beta$-glucosidases, FPA and xylanases}

The endoglucanase production was the lowest in solid-state cultivation containing only FRC (100\% FRC) compared with the other cultures (Figure 1A). However, the 96-hour cultivation in which the WB was replaced by $25 \%$ FRC $(75 \% \mathrm{WB}+25 \%$ FRC) had similar enzyme activity compared with the control cultivation. There were higher endoglucanase activity values in 144-hour (210.5 $\pm 5.8 \mathrm{U} / \mathrm{g}$ ) cultivation; however, the cultivations were not significantly different $(100 \% \mathrm{WB}, 75 \% \mathrm{WB}+25 \%$ FRC or $50 \% \mathrm{WB}+50 \% \mathrm{FRC})$.

For $\beta$-glucosidase (Fig. 1B), the highest activity was observed at 96 hours $(22.62 \mathrm{U} / \mathrm{g})$ in the $75 \% \mathrm{WB}+$ $25 \%$ FRC medium. At 120 hours, there was an increase in $\beta$-glucosidase activity in the $50 \% \mathrm{WB}+50 \% \mathrm{FRC}$ and $100 \%$ FRC media; however, the cultures were not significantly different. At 144 hours, the $\beta$-glucosidase enzyme activity was statistically indistinguishable for all media, with the exception of the FRC only medium (FRC $100 \%$ ), which had decreased enzyme activity compared with 120 hours.

The FPA of the $75 \% \mathrm{WB}+25 \%$ FRC media was superior to the control $(100 \% \mathrm{WB})$ at 120 hours. Although the average of the $75 \% \mathrm{WB}+25 \% \mathrm{FRC}$ was higher at 144 hours $(24.22 \pm 0.25 \mathrm{U} / \mathrm{g})$, the results were not significantly different from the $100 \% \mathrm{WB}$ and $50 \% \mathrm{WB}+50 \%$ FRC treatments. The lowest FPA was observed using 100\% FRC and $25 \% \mathrm{WB}+75 \%$ FRC (Figure 1C).

The highest xylanase enzyme activity (Figure 1D) was obtained with the $100 \%$ WB medium after 144 hours of cultivation $(1137.59 \pm 4.76 \mathrm{U} / \mathrm{g})$. All cultures containing FRC had lower activities, with increasing FRC concentrations resulting in lower xylanase production.

\section{Evaluation of fungal mass and $\mathrm{pH}$ of the cultures}

The mycelial masses in various SSCs using the fungus $P$. echinulatum $\mathrm{S} 1 \mathrm{M} 29$ are shown in Figure 2. The mycelial mass was estimated indirectly by analyzing the production of $\mathrm{N}$-acetyl-D-glucosamine from the enzymatic hydrolysis of chitin in the fungal cell wall after 120 hours of cultivation.

The mycelial mass is proportional to the ratio of WB present in the medium; as the WB concentration increased, the mycelial mass increased. It was determined that that there was no direct relationship between enzymatic activities and mycelial mass for the evaluated enzymes (Figure 2).

The $\mathrm{pH}$ profile was measured in the experimental cultures (Figure 3). It was determined that for 48 hours there was no $\mathrm{pH}$ change; however, at 96 hours, there was acidification in all cultures. During this period, there was potentially carbon source consumption in the medium that resulted in acidification, with the $\mathrm{pH}$ reaching values near 4.0. After 96 hours, when there was increased enzymatic activity, the $\mathrm{pH}$ values increased to between 6.0 and 7.0. These data indicate that there is a correlation between $\mathrm{pH}$ and growth; these findings are according to Sternberg and Dorval (1979). They interpreted the $\mathrm{pH}$ variation in Trichoderma reesei cultures as a period of growth and $\mathrm{NH}_{3}$ uptake, which released $\mathrm{H}^{+}$into the medium, while the $\mathrm{pH}$ increase at the end of the cultivation was due to $\mathrm{NH}_{3}$ secretion by the fungus. This hypothesis is potentially corroborated by the results of the present work because the $100 \% \mathrm{WB}$ cultures had the lowest $\mathrm{pH}$ and had the highest growth (Figure 2). There were lower $\mathrm{pH}$ values in the WB only medium after 48 hours of cultivation. These results are contrary to the results observed by Camassola and Dillon (2007); however, in that study, the WB was complexed with cane sugar bagasse.

Identical results can be observed when comparing enzymatic production using $A$. niger NRRL 567 (Dhillon et al., 2012); however, the FPA values were very high compared with other studies. A mixed culture of T. reesei and A. niger (Dhillon et al., 2011) had relatively similar enzyme concentrations compared with $P$. echinulatum S1M29 in $75 \% \mathrm{WB}+25 \%$ FRC medium, demonstrating the potential use of FRC for the production of enzymes that mediate lignocellulose hydrolysis (Table 2). 

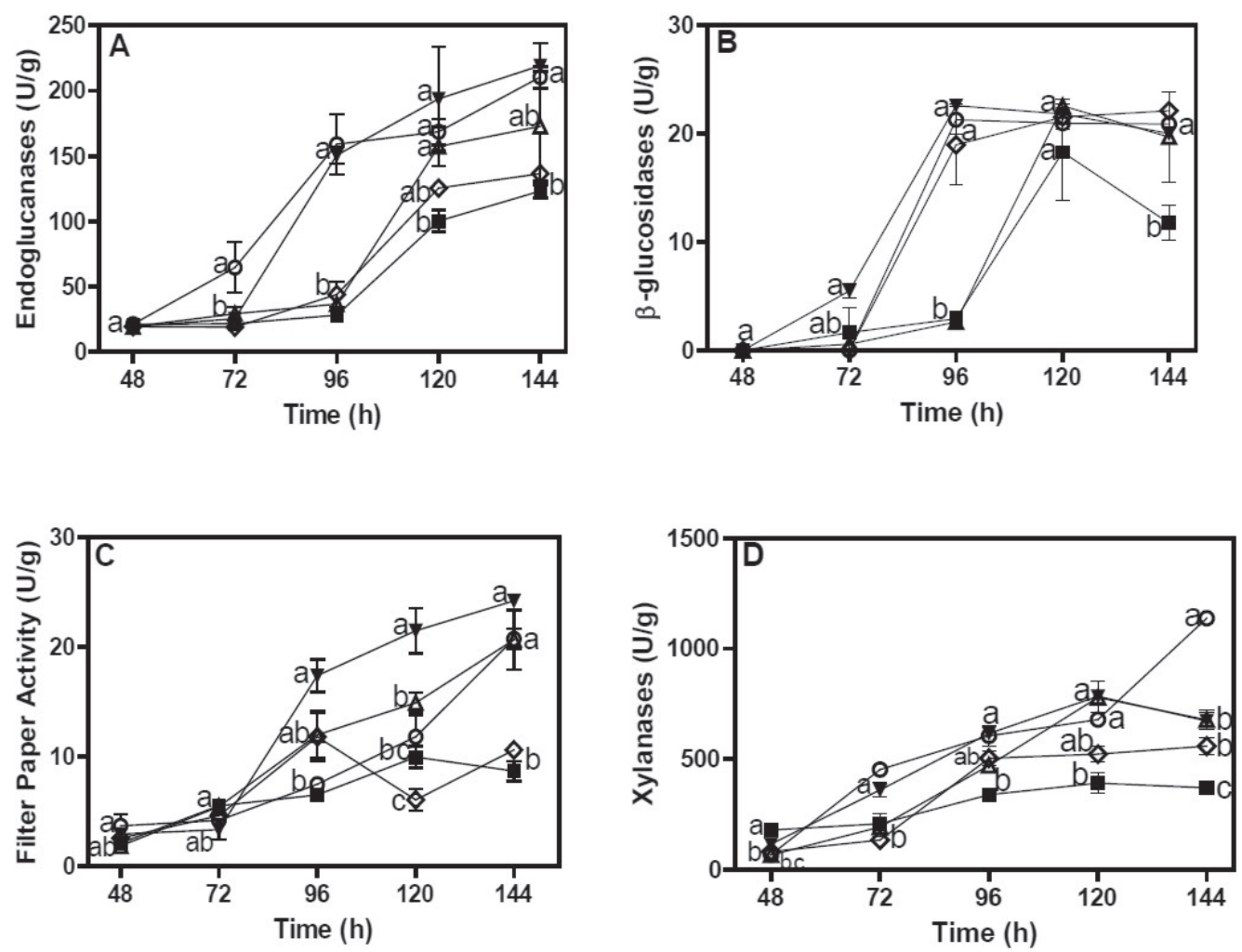

\section{$100 \% \mathrm{FRC} \bullet \mid 100 \% \mathrm{WB} \triangle 50 \% \mathrm{WB}+50 \% \mathrm{FRC} \rightarrow 75 \% \mathrm{WB}+25 \% \mathrm{FRC} \diamond 25 \% \mathrm{WB}+75 \% \mathrm{FRC}$}

Figure 1. Activities of endoglucanases (A), $\beta$-glucosidases (B) FPA (C) and xylanase (D) in solid-state cultivation with Penicillium echinulatum S1M29 in various culture media using fodder radish cake and wheat bran as a substrate. The treatment means that have the same letters for the same day are not significantly different when evaluated using Tukey's test ( $\mathrm{p}>0.05$ ). WB - wheat bran; FRC - fodder radish cake.

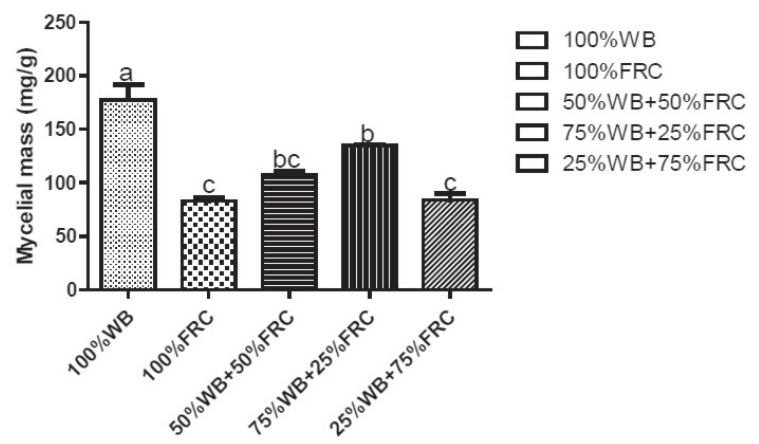

Figure 2. Mycelial mass concentrations in solid-state cultivation using Penicillium echinulatum S1M29 after 120 hours of cultivation in media with different formulations.

WB - wheat bran; FRC - fodder radish cake.

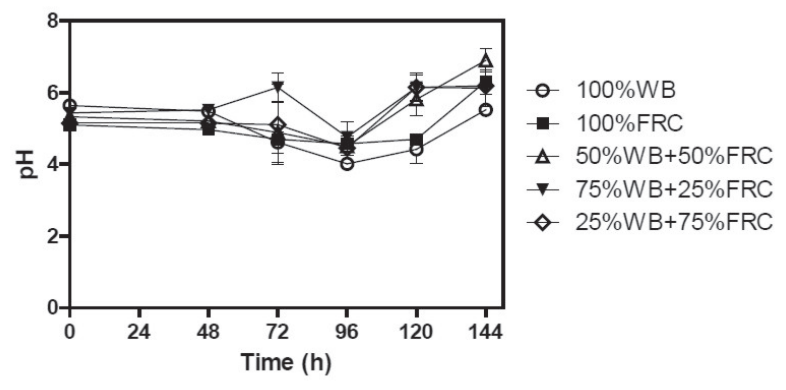

Figure 3. Variations of $\mathrm{pH}$ at different time points during the solidstate cultivation using Penicillium echinulatum S1M29. 
Table 2. Comparisons of enzyme activities for different microorganisms grown on various lignocellulosic substrates.

\begin{tabular}{|c|c|c|c|c|c|c|}
\hline \multirow{2}{*}{ Microorganism } & \multirow{2}{*}{ Substrates } & \multicolumn{4}{|c|}{ Enzyme activities (U/g) } & \multirow{2}{*}{ References } \\
\hline & & FPA & Endoglucanase & $\beta$-glucosidase & Xylanases & \\
\hline P. echinulatum S1M29 & $75 \% \mathrm{WB}+25 \% \mathrm{FRC}$ & 24.22 & 210.5 & 22.62 & 784.73 & This Study \\
\hline P. echinulatum S1M29 & $100 \%$ FRC & 9.98 & 123.17 & 18.31 & 392.10 & This Study \\
\hline P. echinulatum 9A02S1 & $\begin{array}{c}\text { Sugar cane bagasse } \\
+ \text { WB }\end{array}$ & 32.89 & 282.36 & 58.95 & 10.0 & $\begin{array}{l}\text { Camassola and Dillon, } \\
\text { (2007) }\end{array}$ \\
\hline A. niger NS-2 & Sugar cane bagasse & 3.0 & 5.0 & 0.03 & - & Bansal et al., (2012) \\
\hline T. asperellum SR1-7 & WB & 2.2 & 13.13 & 9.2 & - & $\begin{array}{l}\text { Raghuwanshi et al. } \\
\qquad(2014)\end{array}$ \\
\hline T. reesei $+A$. niger & WB & 22.89 & 117.71 & 24.54 & 2.71 & Dhillon et al. (2011) \\
\hline A. niger NRRL 567 & $\begin{array}{l}\text { Rice husk }+ \text { Apple } \\
\text { pomace }\end{array}$ & 113.68 & 172.3 & 60.09 & - & Dhillon et al. (2012) \\
\hline A. fumigatus SK1 & Oil palm trunk & 3.36 & 54.27 & 4.51 & 418.70 & Ang et al. (2012) \\
\hline
\end{tabular}

The results indicated that FRC alone did not produce adequate cellulase and xylanase levels during solid-state cultivation. However, the replacement of $25 \%$ of the WB with FRC may be favorable for the production of cellulases because higher values were observed for FPA activity and $\beta$-glucosidases in cultures grown in this media. These experiments are relevant because they indicate that WB could be replaced by up to $25 \%$ for cellulase production in solid-state cultivation.

\section{CONCLUSIONS}

The present study has demonstrated that fodder radish cake can be employed as a component in media for cellulase production during P. echinulatum solid-state cultivation. Specifically, this study determined that up to $25 \% \mathrm{WB}$, a traditional substrate for cellulase production, may be substituted and is advantageous for cellulase production. Therefore, using FRC as an alternative carbon source to partially replace WB may lower the costs of producing enzyme complexes, which may in turn reduce the production costs of cellulosic ethanol.

\section{ACKNOWLEDGEMENTS}

The authors are grateful to the financial and technical support of UCS, CAPES (scholarship), CNPq (310590/2009-4), and FAPERGS (10/1972-5).

\section{REFERENCES}

Ang, T.N., Ngoh, G.C., Chua, A.S., Lee, M.G. Elucidation of the effect of ionic liquid pretreatment on rice husk via structural analyses. Biotechnology for Biofuels, 5, 67 (2012).

Ávila, R.N.d.A., Sodré, J.R. Physical-chemical properties and thermal behavior of fodder radish crude oil and biodiesel. Industrial Crops and Products, 38, 54-57 (2012).
Bansal, N., Tewari, R., Soni, R., Soni, S.K. Production of cellulases from Aspergillus niger NS-2 in solid-state fermentation on agricultural and kitchen waste residues. Waste Management, 32, 1341-1346 (2012).

Basso, V., Machado, J.C., da Silva Lédo, F.J., da Costa Carneiro, J., Fontana, R.C., Dillon, A.J.P., Camassola, M. Different elephant grass (Pennisetum purpureum) accessions as substrates for enzyme production for the hydrolysis of lignocellulosic materials. Biomass and Bioenergy, 71, 155161 (2014).

Camassola, M., Dillon, A.J. Cellulases and xylanases production by Penicillium echinulatum grown on sugar cane bagasse in solid-state fermentation. Applied Biochemistry and Biotechnology, 162, 1889-1900 (2010).

Camassola, M., Dillon, A.J.. Production of cellulases and hemicellulases by Penicillium echinulatum grown on pretreated sugar cane bagasse and wheat bran in solid-state fermentation. Journal of Applied Microbiology, 103, 21962204 (2007).

Camassola, M., Dillon, A.J.P. Cellulase determination: modifications to make the filter paper assay easy, fast, practical and efficient. doi:10.4172/scientificreports. 125 (2012).

Camassola, M., Dillon, A.J.P. Steam-exploded sugar cane bagasse and wheat bran in solid-state cultivation to produce cellulases and xylanases from Penicillium echinulatum. Brazilian Journal of Chemical Engineering, accepted manuscript (2016).

Daroit, D.J., Simonetti, A., Hertz, P.F., Brandelli, A. Purification and characterization of an extracellular beta-glucosidase from Monascus purpureus. Journal of Microbiology and Biotechnology, 18, 933-941 (2008).

Dhillon, G.S., Kaur, S., Brar, S.K., Verma, M. Potential of apple pomace as a solid substrate for fungal cellulase and hemicellulase bioproduction through solid-state fermentation. Industrial Crops and Products, 38, 6-13 (2012).

Dhillon, G.S., Oberoi, H.S., Kaur, S., Bansal, S., Brar, S.K. Value-addition of agricultural wastes for augmented cellulase and xylanase production through solid-state tray fermentation 
employing mixed-culture of fungi. Industrial Crops and Products, 34, 1160-1167 (2011).

Dillon, A.J., Bettio, M., Pozzan, F.G., Andrighetti, T., Camassola, M. A new Penicillium echinulatum strain with faster cellulase secretion obtained using hydrogen peroxide mutagenesis and screening with 2-deoxyglucose. Journal of Applied Microbiology, 111, 48-53 (2011).

Dillon, A.J., Zorgi, C., Camassola, M., Henriques, J.A. Use of 2-deoxyglucose in liquid media for the selection of mutant strains of Penicillium echinulatum producing increased cellulase and beta-glucosidase activities. Applied Microbiology and Biotechnology, 70, 740-746 (2006).

Domingos, A.K., Saad, E.B., Wilhelm, H.M., Ramos, L.P. Optimization of the ethanolysis of Raphanus sativus (L. Var.) crude oil applying the response surface methodology. Bioresource Technology, 99, 1837-1845 (2008).

Ghose, T.K. Measurement of cellulase activities. Pure Appl Chem, 59(2), 257-268 (1987).

Herold, S., Bischof, R., Metz, B., Seiboth, B., Kubicek, C.P. Xylanase gene transcription in Trichoderma reesei is triggered by different inducers representing different hemicellulosic pentose polymers. Eukaryotic Cell, 12, 390-398 (2013).

Mabee, W.E., McFarlane, P.N., Saddler, J.N. Biomass availability for lignocellulosic ethanol production. Biomass and Bioenergy, 35, 4519-4529 (2011).

Macedo, E.P., Cerqueira, C.L.O., Souza, D.A.J., Bispo, A.S.R., Coelho, R.R.R., Nascimento, R.P. Production of cellulosedegrading enzyme on sisal and other agro-industrial residues using a new Brazilian actinobacteria strain Streptomyces sp. SLBA-08. Brazilian Journal of Chemical Engineering, 30, 729-735 (2013).

Martins, L.F., Kolling, D., Camassola, M., Dillon, A.J., Ramos, L.P. Comparison of Penicillium echinulatum and Trichoderma reesei cellulases in relation to their activity against various cellulosic substrates. Bioresource Technology, 99, 1417-24 (2008).

Miller, G.L. Use of dinitrosalicylic acid reagent for determination of reducing sugar. Analytic Chemistry, 31, 426-428 (1959).
Novello, M., Vilasboa, J., Schneider, W.D.H., Reis, L., Fontana, R.C., Camassola, M. Enzymes for second generation ethanol: exploring new strategies for the use of xylose. RSC Advances, 4, 21361-21368 (2014).

Padilha, I.Q.M., Carvalho, L.C.T., Dias, P.V.S., Grisi, T.C.S.L., Silva, F.L.H.d., Santos, S.F.M., Araújo, D.A.M. Production and characterization of thermophilic carboxymethyl cellulase synthesized by Bacillus sp. growing on sugarcane bagasse in submerged fermentation. Brazilian Journal of Chemical Engineering, 32, 35-42 (2015).

Pirota, R.D.P.B., Miotto, L.S., Delabona, P.S., Farinas, C.S. Improving the extraction conditions of endoglucanase produced by Aspergillus niger under solid-state fermentation. Brazilian Journal of Chemical Engineering, 30, 117-123 (2013).

Raghuwanshi, S., Deswal, D., Karp, M., Kuhad, R.C. Bioprocessing of enhanced cellulase production from a mutant of Trichoderma asperellum RCK2011 and its application in hydrolysis of cellulose. Fuel, 124(0), 183-189 (2014).

Reis, L., Ritter, C.E.T., Fontana, R.C., Camassola, M., Dillon, A.J.P. Statistical optimization of mineral salt and urea concentration for cellulase and xylanase production by Penicillium echinulatum in submerged fermentation. Brazilian Journal of Chemical Engineering, 32, 13-22 (2015).

Reis, L., Schneider, W., Fontana, R., Camassola, M., Dillon, A.P.. Cellulase and Xylanase Expression in Response to Different $\mathrm{pH}$ Levels of Penicillium echinulatum S1M29 Medium. BioEnergy Research, 7, 60-67 (2014).

Sluszz, T., Machado, J.A.D. Características das potenciais culturas matérias-primas do biodiesel e sua adoção pela agricultura familiar. In Proceedings of the 6. Encontro de Energia no Meio Rural, Campinas (SP, Brazil)

Sternberg, D., Dorval, S. Cellulase production and ammonia metabolism in Trichoderma reesei on high levels of cellulose. Biotechnology and Bioengeering, 21, 181-91 (1979).

Yoon, L.W., Ang, T.N., Ngoh, G.C., Chua, A.S.M. Fungal solidstate fermentation and various methods of enhancement in cellulase production. Biomass and Bioenergy, 67, 319-338 (2014). 